\title{
Effects of temperature, fungal infection and weight on intermoult duration and survival of starving larvae in the European earwig
}

Martin Coulm, Joël Meunier*

Institut de Recherche sur la Biologie de l'Insecte (IRBI), UMR 7261, CNRS, University of Tours, Tours, France

${ }^{*}$ Corresponding authors: joel.meunier@univ-tours.fr

\begin{abstract}
Moulting is a cornerstone of arthropods development. It can be determined by numerous factors such as body mass, temperature, and immunity. However, the effects of these factors can be dependent on each other, so that it is often difficult to predict whether and how they shape moulting, and whether their effects are additive or interactive. In this study, we addressed these questions by testing the effects of body mass, ambient temperature, fungal infection and their interaction on intermoult duration and survival in starved juveniles of the European earwig Forficula auricularia. We recorded the date of moult and death of a total of 207 earwig juveniles that were weighed, exposed to different doses of the entomopathogenic fungus Metarizium brunneum and then maintained at either $20^{\circ} \mathrm{C}$ or $24^{\circ} \mathrm{C}$. Our results first reveal that juveniles moulted earlier when they were heavy compared to light on the day of exposure, as well as earlier when maintained at $24^{\circ} \mathrm{C}$ compared to $20^{\circ} \mathrm{C}$. By contrast, pathogen exposure did not affect the moulting date. We also found that nymphs died faster when they were light compared to heavy on the day of exposure, when they were exposed to high $\left(10^{6}\right.$ and $10^{7}$ spores $\left./ \mathrm{ml}\right)$ compared to low $\left(10^{4}, 10^{5}\right.$ and 0 spores $/ \mathrm{ml}$ ) pathogen concentrations, and when they were maintained at $24^{\circ} \mathrm{C}$ compared to $20^{\circ} \mathrm{C}$. We detected no sign of interaction between temperature, fungal infection and body mass on both moulting and survival. Overall, these findings shed light on the limited importance of infection on moulting in starved juveniles, and reveal that weight, temperature, and infection have additive effects on their survival. More generally, this study emphasizes that the three tested factors do not necessarily interact to shape key physiological processes in an insect.
\end{abstract}

KEYWORDS: Arthropod; Development; Dermaptera; Fungus; Survival 


\section{INTRODUCTION}

Moulting is often considered a cornerstone of the arthropod life cycle (Chapman and Reynolds, 2013). This is because it is necessary for the development of juveniles as it allows them to develop a body size larger than what their previous cuticle would have allowed, and/or permits the growth (or removal) of specific features that become essential (or unnecessary) during the next stage of the life cycle (Chapman and Reynolds, 2013). However, moulting also comes with costs. The success of this process indeed demands a large amount of energy from the juveniles and the soft cuticle of newly moulted individuals often augments the risks of premature death due to predation or pathogen infection (Lucas et al., 2000; Moret et al., 2010). As a result, moulting or delaying moulting is a critical decision for the youngs in arthropods (Chapman and Reynolds, 2013).

Whereas numerous factors are known to govern the moult of an individual, it remains difficult to predict the occurrence, strength and direction of their effects in a given species (Chapman and Reynolds, 2013; Hutchinson et al., 1997; Nijhout, 1981). For instance, relatively high juveniles weight and food intake are often but not necessarily associated with a rapid moulting, such as in Manduca sexta (Nijhout and Williams, 1974), Oncopeltus fasciatus (Blakley and Goodner, 1978), Drosophila melanogaster (Davidowitz et al., 2016) and other Lepidopteran species (Esperk and Tammaru, 2004). Similarly, pathogen infection can lead to a delayed moulting because it enforces juveniles to re-allocate resources into immune functions at the potential expense of other physiological functions involved in development (Chapman and Reynolds, 2013) or because it can help the hosts to prevent parasites from entering the body (Duneau and Ebert, 2012). Infections may also shape hosts moulting by disturbing the physiological processes involved in its regulation. For instance, some fungal and viral infections change the level of chitinases activity, a class of hydrolases involved in moulting and metamorphosis, and thus modify intermoult durations in the infected hosts (Acuña-Payano et al., 2017; He et al., 2020). Finally, the ambient temperature is a key parameter of the environment that has critical effects on a broad diversity of physiological processes (Beever et al., 2017; Huey, 1976; Kearney et al., 2009; Régnière et al., 2012). Moulting is no exception and numerous studies demonstrate that living under warmer compared to colder temperatures typically speed up larval development and precipitates moulting in many species (Abarca et al., 2020; Lehtovaara et al., 2018; Stamp, 1990; Stamp and Osier, 1998).

One reason why it remains difficult to understand what factors determine moulting and how they do it is that these factors can act on each other, and the outcome of these interactions is often unclear. This is the case of ambient temperature and infection. Temperature changes can indeed shift the metabolic rates of both hosts and pathogens, which in turn may alter hosts immunity and capability to control and tolerate an infection (Catalán et al., 2012; Murdock et al., 2012; Thomas and Blanford, 2003; Wojda, 2017), as well as modify parasites pathogenicity and possibility to reach new hosts (Adamo and Lovett, 2011; Linder et al., 2008; Ment et al., 2011; Pamminger et al., 2016; Thomas and Blanford, 2003). Depending on the host-pathogen system, these reciprocal effects lead to cases where infected individuals survive better to infection when maintained under high compared to low ambient temperatures (Kryukov et al., 2018; Lysyk and Selinger, 2012), and other cases where infected individuals survive less well under high compared to low ambient temperatures (Li et al., 1995; Linder et al., 2008; Yilmaz et al., 2013). Whether and how the interaction between ambient temperatures and infection affects moulting remains poorly investigated.

In this study, we tested whether and how body mass, ambient temperature, pathogen infection and the interaction between these parameters affect the second moulting and survival of starved juveniles in the European earwig Forficula auricularia L (Dermaptera: Forficulinae). In European populations of this species, eggs typically develop during 40 days in winter, from which larvae (called nymphs) reach adulthood after about two months (Meunier et al., 2012; Ratz et al., 2016). A recent study revealed that this species has 5 moulting events: its first moult (called 
intermediate moult) takes place during egg hatching so that the nymphs that emerge from the eggs are already in their $2^{\text {nd }}$ developmental instar (Tourneur et al., 2020). These newly hatched (i.e. $2^{\text {nd }}$ instar) nymphs take from 9 to 15 days to moult into the following instar (i.e. $3^{\text {rd }}$ instar) and the mean duration of this (and the other) stage varies between populations - partly due to local adaptations to temperature regimes (Meunier et al., 2012; Ratz et al., 2016; Tourneur and Meunier, 2020; Tourneur et al., 2020). Earwig eggs are sensitive to ambient temperatures, as a prolongation of winter duration during egg development postpone egg hatching date and then extend juveniles development until adulthood (Gingras and Tourneur, 2001; Körner et al., 2018). The direct effects of ambient temperatures and pathogen infection on moulting and survival are unknown in this species.

Here, we conducted a $6 \times 2$ full-factorial experiment in which we weighted $2^{\text {nd }}$ instar nymphs and exposed them to one of six suspensions containing (or not) spores of the entomopathogenic fungus Metarhizium brunneum. We then maintained these juveniles at either $20^{\circ} \mathrm{C}$ or $24^{\circ} \mathrm{C}$ and subsequently recorded the days of moult to $3^{\text {rd }}$ instar and the day of death for the next 20 days without providing food during this period. M. brunneum (formerly M. anisopliae) is a natural and lethal pathogen of $F$. auricularia (Arcila and Meunier, 2020; Günther and Herter, 1974; Kohlmeier et al., 2016; Körner et al., 2020; Vogelweith et al., 2017) for which the optimal temperatures of infections typically range between 20 and $30^{\circ} \mathrm{C}$, with an optimum around $25^{\circ} \mathrm{C}$ (Arthurs and Thomas, 2001).

\section{MATERIAL AND METHODS}

\section{Experimental setup}

Our experiment involved a total of $207 \mathrm{~F}$. auricularia nymphs. These nymphs were produced by 20 earwig mothers field sampled in 2018 in Pont-de-Ruan (France) and then maintained under standard laboratory conditions until nymph production (Meunier et al., 2012). In brief, field sampled females and males were transferred into large plastic containers to allow uncontrolled mating (Sandrin et al., 2015). These containers were maintained at $18{ }^{\circ} \mathrm{C}$, under a $12: 12 \mathrm{~h}$ Light:Dark cycle and received ad libitum homemade food mainly consisting of pollen, cat and bird food, wheat germ and agar (Kramer et al., 2015). Four months later, each female was isolated in a Petri dish (diameter $9 \mathrm{~cm}$ ) lined with wet sand and maintained at $10^{\circ} \mathrm{C}$ under constant darkness to trigger nest construction and oviposition (Körner et al., 2018). At egg oviposition, each Petri dish was maintained at $15^{\circ} \mathrm{C}$ with a $10: 14 \mathrm{~h}$ Light:Dark cycle. At egg hatching (egg development lasts about 50 days in this species; Ratz et al., 2016; Tourneur et al., 2020), each Petri was transferred to a novel climate chamber set up at $18^{\circ} \mathrm{C}$ with a $12: 12 \mathrm{~h}$ Light:Dark cycle, where each family (i.e. a mother and its newly hatched groups of nymphs) received ad libitum homemade food. This food was renewed two days later (i.e. day 3 after egg hatching).

On day 5 after egg hatching, we selected a random subset of 3 to 12 nymphs per family (mean \pm SE $=10.4 \pm 0.6$ ), weighed each of them to the nearest $0.01 \mathrm{mg}$ with a microbalance (OHAUSC Discovery DV215CD) and isolated them in new Petri dishes (diameter $3.5 \mathrm{~cm}$ ). These Petri dishes were lined with humid sand (which ensures a high level of humidity and thus favours fungal development), contained ad libitum homemade food and were maintained under a 12:12 h Light:Dark cycle. One day later (i.e. day 6 after egg hatching), each nymph was exposed to either one of four pathogen suspensions or one of two control solutions using a protocol adapted from fungal exposures of adult earwigs (Arcila and Meunier, 2020; Kohlmeier et al., 2016). Each nymph was first gently deposited on a filter paper (Macherey-Nagel GmbH \& Co. KG, Düren, Germany), then covered with $100 \mu \mathrm{L}$ of either a conidiospore suspension of $M$. brunneum diluted in $0.05 \%$ Tween 20 at a concentration of $10^{4}(n=33), 10^{5}(n=35), 10^{6}(n=35)$ or $10^{7}(n=34)$ spores $/ \mathrm{ml}$, with $100 \mu \mathrm{L}$ of a control spore-free solution of either $0.05 \%$ Tween $20(n=35$; Sigma P-1379) or control water solution $(n=35)$. After a few seconds, the nymphs were transferred to their original Petri 
dishes, the food was removed, and the nymphs then maintained at either $20^{\circ} \mathrm{C}$ or $24^{\circ} \mathrm{C}$ during the following 20 days. This allowed us to obtain a 6x2 full factorial design with 16 to 18 replicates per fungal concentration and temperature (Table 1). The Petri dishes were checked daily to record the day of death and, if applicable, the day of moult in the $3^{\text {rd }}$ developmental instar. Note that nymphs received no food after exposure (i.e. after day 6) to induce an (extreme) nutritional stress, a phenomenon often experienced by predators such as earwigs under natural conditions (Bilde and Toft, 1998; White, 1978), and to allow us focusing on their intrinsic physiological response to pathogen exposure and temperature.

Table 1 - Number of nymphs used in the statistical models testing nymphs' survival and moulting day depending on temperature and fungal concentration treatments.

\begin{tabular}{c|cc|cc}
\multirow{2}{*}{} & \multicolumn{3}{|c|}{ Survival rate } & \multicolumn{3}{c}{ Moulting day } \\
\cline { 2 - 5 } & $20^{\circ} \mathrm{C}$ & $24^{\circ} \mathrm{C}$ & $20^{\circ} \mathrm{C}$ & $24^{\circ} \mathrm{C}$ \\
\hline Water & 18 & 17 & 10 & 6 \\
Tween & 17 & 18 & 9 & 10 \\
$10^{4}$ spores $/ \mathrm{ml}$ & 17 & 16 & 11 & 9 \\
$10^{5}$ spores $/ \mathrm{ml}$ & 18 & 17 & 9 & 5 \\
$10^{6}$ spores $/ \mathrm{ml}$ & 17 & 18 & 7 & 6 \\
$10^{7}$ spores $/ \mathrm{ml}$ & 18 & 16 & 6 & 5 \\
\hline Total & \multicolumn{3}{|c|}{207} & \multicolumn{3}{|c}{93} \\
\hline
\end{tabular}

\section{Statistical analyses}

Nymphs' survival and moulting day were analysed using Mixed effects Cox proportional hazard regression models (function coxme in $\mathrm{R}$ ) allowing for censored data; that is, nymphs alive 20 days after exposure and still in their $2^{\text {nd }}$ developmental instar 10 days after exposure, respectively. In these models, fungal concentration (Water, Tween, and $10^{4}, 10^{5}, 10^{6}$ or $10^{7} \mathrm{spores} / \mathrm{ml}$ ), temperature $\left(20^{\circ} \mathrm{C}\right.$ or $\left.24^{\circ} \mathrm{C}\right)$, nymph fresh weight at exposure (continuous) and all interactions among these factors were entered as explanatory factors. Because some nymphs originate from the same families, the ID of the family of origin of each nymph was entered into the models as a random effect. The model on nymphs survival involved the 207 tested nymphs, while the model on nymphs moulting day involved the 93 nymphs that either moulted in the $3^{\text {rd }}$ instar within 10 days post-exposure or remained alive and in their $2^{\text {nd }}$ instar 10 days post-exposure (Table 1). We chose day 10 post-exposure because nymphs typically moult in the $3^{\text {rd }}$ instar 12 days after egg hatching in this species (Meunier et al., 2012; Ratz et al., 2016), which corresponds to 6 days post-exposure in our experiment. Moreover, $M$. brunneum spores typically penetrate the host cuticle within 72h after exposure (Aw and Hue, 2017), suggesting that the tested nymphs were infected at the expected time of moulting, i.e. 6 days post-exposure. Pairwise comparisons between types of exposures were conducted using estimated marginal means (i.e. least-square means) and p-values corrected for multiple testing using Tukey method. Because the main goal of this study was to investigate potential interactions between temperature and infection, this interaction was never removed during the process of model simplification via AIC comparison. Nevertheless, removing this non-significant interaction does not qualitatively change the results (Table S1). All statistical analyses were conducted using R v.4.0.4 (http://www.r-project.org/) 
loaded with the packages Coxme (Therneau, 2020), emmeans (Lenth, 2021) and car (Fox and Weisberg, 2019).

\section{RESULTS}

The 207 tested nymphs died during the experiment. Overall, fungal concentration shaped the speed of nymph death (Figure $1 \mathrm{~A}$; Wald $\mathrm{X}_{5}{ }_{5}=56.23, \mathrm{P}<0.0001$ ): nymphs died faster when they were exposed to high fungal doses (i.e. $10^{6}$ and $10^{7}$ spores $/ \mathrm{ml}$ ) compared to control and low fungal doses (i.e. $10^{4}$ and $10^{5}$ spores $/ \mathrm{ml}$; Table 2). Nymphs also died overall faster when maintained at $24^{\circ} \mathrm{C}$ compared to $20^{\circ} \mathrm{C}$ (Figure $1 \mathrm{~B}$; Wald $X^{2}{ }_{1}=100.06, P<0.0001$ ), and when they were light compared to heavy on the day of exposure (Figure $1 \mathrm{C}$; Wald $X^{2}{ }_{1}=14.05, P=0.0002$ ). By contrast, the speed of nymphs death was independent of interaction between fungal concentration and temperature (Wald $X^{2}{ }_{5}=5.17, P=0.396$ ) and any other interaction (all $P>0.33$ ).

(A)

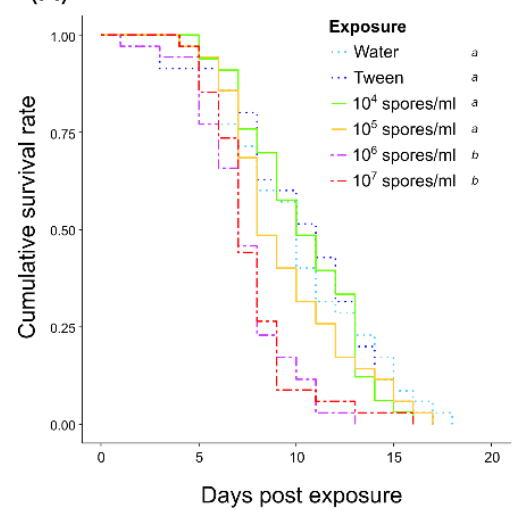

(B)

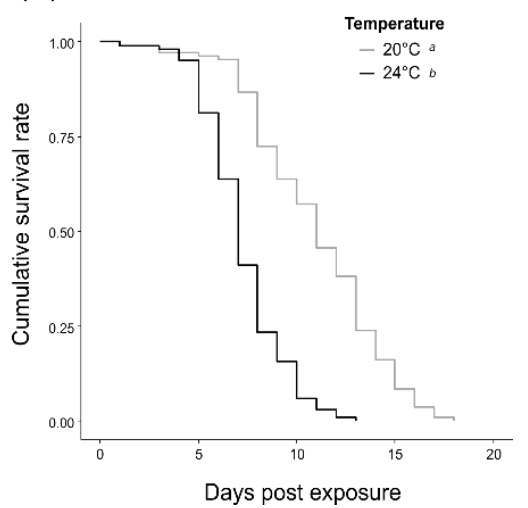

(C)

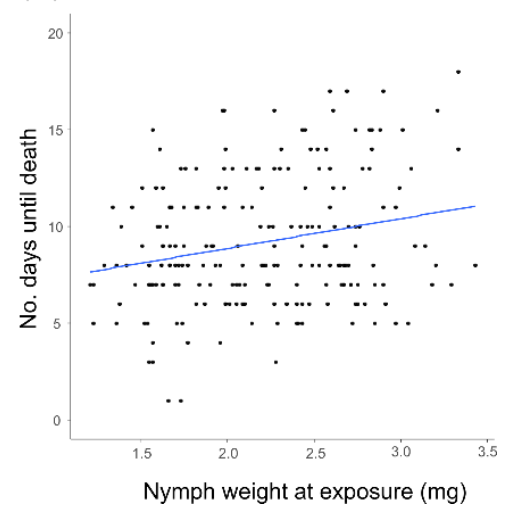

Figure 1 - Effects of $(A)$ fungal concentration, $(B)$ temperature and $(C)$ fresh weight on nymphs' survival rate. Day 0 refers to the day of pathogen exposure. Different letters refer to $P<0.025$.

Table 2 - Pairwise comparisons between the effects of types of exposure of nymphs' survival. P-values obtained using estimated marginal means and corrected for multiple testing using Tukey method. Significant $p$-values are in bold.

\begin{tabular}{c|ccccc} 
& Water & Tween & $10^{4}$ spores $/ \mathrm{ml}$ & $10^{5} \mathrm{spores} / \mathrm{ml}$ & $10^{6} \mathrm{spores} / \mathrm{ml}$ \\
\hline Tween & 0.9919 & - & - & - & - \\
$10^{4} \mathrm{spores} / \mathrm{ml}$ & 0.9960 & 0.8795 & - & - & - \\
$10^{5} \mathrm{spores} / \mathrm{ml}$ & 0.9958 & 0.8700 & 1.0000 & - & - \\
$10^{6} \mathrm{spores} / \mathrm{ml}$ & $<0.0001$ & $<0.0001$ & $<0.0001$ & $<0.0001$ & - \\
$10^{7} \mathrm{spores} / \mathrm{ml}$ & 0.0001 & $<0.0001$ & 0.0006 & 0.0009 & 0.9247 \\
\hline
\end{tabular}

Of the 207 tested nymphs, 114 nymphs died without reaching the $3^{\text {rd }}$ developmental instar within the 10 days following exposure and were thus not used to analyse the moulting date. The 93 other nymphs moulted earlier when maintained at $24^{\circ} \mathrm{C}$ compared to $20^{\circ} \mathrm{C}$ (Figure 2B; Wald $\left.X^{2}{ }_{1}=52.33, P<0.0001\right)$ and when they were heavy compared to light on the day of exposure (Figure $2 \mathrm{C}$; Wald $X^{2}{ }_{1}=5.06, P=0.025$ ). By contrast, this moulting speed was independent of 
fungal concentration (Figure 2A; Wald $X^{2}{ }_{5}=7.86, P=0.164$ ) and any other interaction (all $P>$ 0.52). Because the high mortality rate strongly reduced the number of replicates available per combination (table 1), we confirmed the robustness of our findings by running the same statistical model using a new fungal concentration factor with 2 instead of 5 levels. In this new factor, we pooled values from treatments that did not differ in survival to obtain either high $\left(10^{6}\right.$ and $10^{7}$ spores $/ \mathrm{ml}$, which leads to 25 replicates) or low (Water, Tween, $10^{4}$ and $10^{5} \mathrm{spores} / \mathrm{ml}$, which leads to 68 replicates) fungal concentrations. The results were comparable to those of the first analysis: nymphs moulted earlier when maintained at $24^{\circ} \mathrm{C}$ compared to $20^{\circ} \mathrm{C}$ (Wald $x^{2}{ }_{1}=47.43, \mathrm{P}<$ 0.0001 ), when they were heavy compared to light on the day of exposure (Wald $X^{2}{ }_{1}=6.66, P=$ 0.010), and the moulting speed was independent of high/low fungal concentrations (Wald $X^{2}{ }_{1}=$ $0.44, P=0.505$ ) and any other interaction (all $P>0.127$ ).

(A)

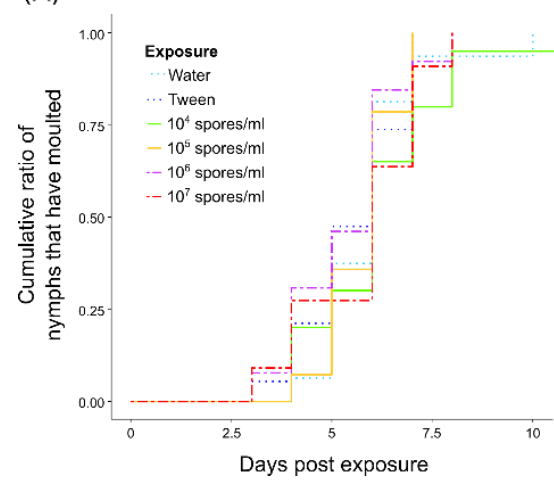

(B)

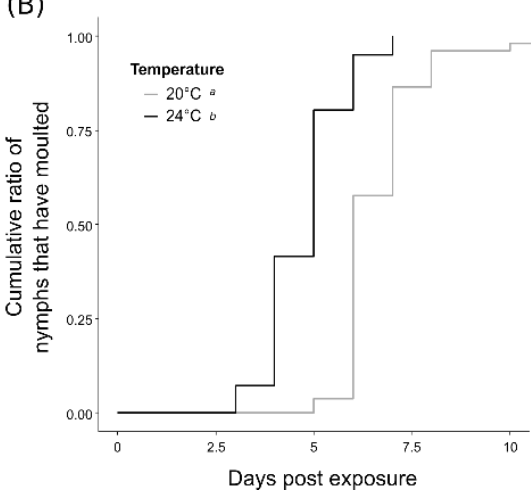

(C)

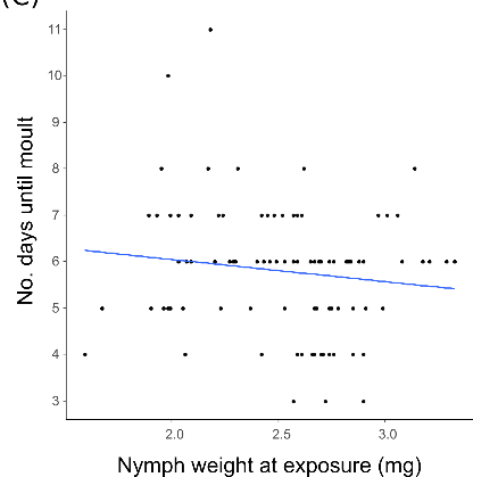

Figure 2 - Effects of (A) fungal concentration, $(B)$ temperature and $(C)$ fresh weight on nymphs' moulting day. Day 0 refers to the day of pathogen exposure. Different letters refer to $P<0.025$.

\section{DISCUSSION}

In this study, we investigated whether and how body mass, ambient temperature and fungal infection affect the intermoult duration and survival rate of starved nymphs in the European earwig. Our results show that moulting occurred more rapidly when nymphs were maintained at $24^{\circ} \mathrm{C}$ compared to $20^{\circ} \mathrm{C}$, and when nymphs exhibited a larger compared to smaller body mass. The level of infection did not affect moulting. The nymphs also died faster after exposure to high compared to low concentrations of fungal spores, when maintained at $24^{\circ} \mathrm{C}$ compared to $20^{\circ} \mathrm{C}$ and when exhibiting small compared to large body mass. Finally, we did not detect the effects of an interaction between ambient temperature, infection and/or body mass on the moult date and survival rate of the tested nymphs.

Our results first reveal that temperature is an important parameter in the early development of earwigs because nymphs moulted sooner and survived overall less well at $24^{\circ} \mathrm{C}$ compared to $20^{\circ} \mathrm{C}$. Given that $20^{\circ} \mathrm{C}$ reflects the temperature naturally encountered by $2^{\text {nd }}$ instar nymphs in the tested population, the reduced survival observed at $24^{\circ} \mathrm{C}$ reveals limited plasticity to an increased environmental temperature at this developmental stage, even if long-term adaptation remains possible (Tourneur and Meunier, 2020). Moreover, our findings confirm that earwigs are no exception in that when individuals cannot regulate their body temperature physiologically (which is the case in ectotherms), changes in ambient temperature can affect important physiological 
processes involved in the survival, development and/or reproduction of an individual (Beever et al., 2017; Huey, 1976; Kearney et al., 2009; Régnière et al., 2012). Interestingly, the nature of these effects along thermal gradients is not always easy to predict. In spiders, for instance, exposure to critically low or high ambient temperatures typically augments mortality ( $\mathrm{Li}$ and Jackson, 1996) while increasing temperatures generally speed up juveniles development up to a certain level, after which it becomes delayed (Li and Jackson, 1996). Our results thus call for future works exploring the effects of a broader range of temperatures on survival and development, as well as on the subsequent reproduction of the resulting adults in earwigs.

Our experiment then shows that exposure to M. brunneum spores reduced nymph's survival but did not affect their moulting. These findings first confirm that $M$. brunneum is not only lethal to earwig adults but also to juveniles (Kohlmeier et al., 2016; Vogelweith et al., 2017) and emphasize that this lethality becomes apparent only when nymphs are exposed to suspensions containing more than $10^{6}$ spores $/ \mathrm{ml}$. More surprisingly, we also found that the nymph's infection did not modify moulting. This first suggests that $M$. brunneum does not disturb the biochemical processes involved in moulting regulation, contrary to other pathogenic fungi (Acuña-Payano et al., 2017; He et al., 2020). It also indicates that the potential re-allocation of resources toward immunity after pathogen infection does not shape the development of $2^{\text {nd }}$ instar earwig juveniles and calls for future works investigating whether this reallocation indeed occurs and whether it has long-term effects, such as a shorter survival or delayed development in the subsequent instar (Chapman and Reynolds, 2013). On the other hand, the absence of a trade-off could be explained by the existence of maternal care in this species (Kölliker, 2007; Lamb, 1976): mothers might have taken over juveniles defence against pathogens and juveniles eventually lost the capability to invest (or adjust their investment) in immunity (Meunier, 2015; Rozen et al., 2008) - even in absence of a tending mother such as in the present experiment. However, maternal care is only facultative in the European earwig and a series of experimental works provided no support for a link between maternal care and nymphs resistance against fungal infection in this species (Körner et al., 2020; Vogelweith et al., 2017).

Our data finally suggest that ambient temperature and pathogen infection do not interact to shape nymphs survival and moulting. The occurrence and nature of the link between ambient temperature and immunity are greatly variable among arthropods. For instance in Tenebrio molitor, larvae exhibit a stronger immune response to simulated infection (lipopolysaccharide injection) when maintained under an ambient temperature of $30^{\circ} \mathrm{C}$ compared to $10^{\circ} \mathrm{C}$ or $20{ }^{\circ} \mathrm{C}$ (Catalán et al., 2012). In the wax moth Galleria mellonella, larvae exhibit higher levels of antibacterial and antifungal activities in the hemolymph when maintained at $38^{\circ} \mathrm{C}$ compared to $28^{\circ} \mathrm{C}$ (Wojda and Jakubowicz, 2007). These contrasting patterns are also present when focusing on survival to infection. In the stable fly Stomoxys calcitrans and the wax moth Galleria mellonella, for instance, larvae survive better to infections when maintained at $30^{\circ} \mathrm{C}$ and $34^{\circ} \mathrm{C}$ compared to $15^{\circ} \mathrm{C}$ and $24^{\circ} \mathrm{C}$, respectively (Kryukov et al., 2018; Lysyk and Selinger, 2012). Conversely in the fruit fly $D$. melanogaster, the oblique banded leafroller Christoneura rosaceana and the Pine processionary moth Thaumetopoea wilkinsoni, juvenile stages survive better to infections when maintained under cold compared to warm temperatures (Li et al., 1995; Linder et al., 2008; Yilmaz et al., 2013). Our results thus provide additional pieces of evidence that survival to infection is not necessarily enhanced or deteriorated by ambient temperature, as well as that the effect of temperature on developmental speed is not necessarily altered by an infection in every hostpathogen system.

Overall, our results demonstrate that ambient temperature is an important parameter in the development and survival of starved earwig juveniles, while this parameter does not shape how these juveniles react to infection with $M$. brunneum. They also stress the importance of body mass on moulting and survival in $2^{\text {nd }}$ instar nymphs. Altogether, our study emphasizes that ambient temperature and pathogen infections do not necessarily interact to shape key insects' 
physiological processes such as moulting, and thus stress the need to accumulate data across a broad diversity of species to better understand general patterns governing moulting in arthropods. Because our findings are based on isolated individuals that had no access to a food source and a tending mother, they also call for future works exploring whether family life, food access and maternal care (or even sibling cooperation; Falk et al., 2014) could mitigate or exacerbate the reported effects. For instance, a recent study in the burying beetle Nicrophorus vespilloides showed that parental care buffers against the detrimental effects of low ambient temperature on offspring survival (Grew et al., 2019). Whereas the benefits of maternal presence on nymphs development, immunity and survival are marginal in the European earwig (Kölliker, 2007; Thesing et al., 2015; Vogelweith et al., 2017), predation via sibling cannibalism is frequent during early nymph development (Dobler and Kölliker, 2010) and could thus shape their moulting strategy.

\section{ACKNOWLEDGMENTS}

We thank JC Tourneur and two anonymous reviewers for their comments on this manuscript.

\section{REFERENCES}

Abarca, M., Lill, J.T., Weiss, M.R., 2020. Host plant and thermal stress induce supernumerary instars in caterpillars. Environ. Entomol. 49, 123-131. https://doi.org/10.1093/ee/nvz136

Acuña-Payano, R., Quiroz-Farfán, D., Laynes-Zela, P., Nolasco-Cárdenas, O., Gutiérrez-Román, A., 2017. Hypothenemus hampei (Coleoptera: Curculionidae) induce in vitro laminarinasa y quitinasa de Beauveria bassiana (Hypocreales: Clavicipitaceae). Rev. Colomb. Entomol. $43,7-13$.

Adamo, S.A., Lovett, M.M.E., 2011. Some like it hot: The effects of climate change on reproduction, immune function and disease resistance in the cricket Gryllus texensis. J. Exp. Biol. 214, 1997-2004. https://doi.org/10.1242/jeb.056531

Arcila, F., Meunier, J., 2020. Friend or foe? The apparent benefits of gregarine (Apicomplexa: Sporozoa) infection in the European earwig. Int. J. Parasitol. 50, 461-469. https://doi.org/10.1016/j.jpara.2020.01.007

Arthurs, S., Thomas, M.B., 2001. Effects of temperature and relative humidity on sporulation of Metarhizium anisopliae var. acridum in mycosed cadavers of Schistocerca gregaria. J. Invertebr. Pathol. 78, 59-65. https://doi.org/10.1006/jipa.2001.5050

Aw, K.M.S., Hue, S.M., 2017. Mode of infection of Metarhizium spp. fungus and their potential as biological control agents. J. Fungi 3. https://doi.org/10.3390/jof3020030

Beever, E.A., Hall, L.E., Varner, J., Loosen, A.E., Dunham, J.B., Gahl, M.K., Smith, F.A., Lawler, J.J., 2017. Behavioral flexibility as a mechanism for coping with climate change. Front. Ecol. Environ. 15, 299-308. https://doi.org/10.1002/fee.1502

Bilde, T., Toft, S., 1998. Quantifying food limitation of arthropod predators in the field. Oecologia 115, 54-58. https://doi.org/10.1007/s004420050490

Blakley, N., Goodner, S.R., 1978. Size-dependent timing of metamorphosis in milkweed bugs (Oncopeltus) and its life history implications. Biol. Bull. 155, 499-510. https://doi.org/10.2307/1540786

Catalán, T.P., Wozniak, A., Niemeyer, H.M., Kalergis, A.M., Bozinovic, F., 2012. Interplay between thermal and immune ecology: effect of environmental temperature on insect 
immune response and energetic costs after an immune challenge. J. Insect Physiol. 58, 310-7. https://doi.org/10.1016/j.jinsphys.2011.10.001

Chapman, R.F., Reynolds, S., 2013. Postembryonic development, in: Simpson, S.J., Douglas, A.E. (Eds.), The Insects: Structure and Function. Cambridge, Massachusetts \& London, England, pp. 399-459.

Davidowitz, G., Roff, D., Nijhout, H.F., 2016. Synergism and antagonism of proximate mechanisms enable and constrain the response to simultaneous selection on body size and development time: An empirical test using experimental evolution. Am. Nat. 188, 499-520. https://doi.org/10.1086/688653

Dobler, R., Kölliker, M., 2010. Kin-selected siblicide and cannibalism in the European earwig. Behav. Ecol. 21, 257-263. https://doi.org/10.1093/beheco/arp184

Duneau, D., Ebert, D., 2012. The role of moulting in parasite defence. Proc. R. Soc. London B Biol. Sci. 279, 3049-3054. https://doi.org/10.1098/rspb.2012.0407

Esperk, T., Tammaru, T., 2004. Does the "investment principle" model explain moulting strategies in lepidopteran larvae? Physiol. Entomol. 29, 56-66. https://doi.org/10.1111/j.1365-3032.2004.0365.x

Falk, J., Wong, J.W.Y., Kölliker, M., Meunier, J., 2014. Sibling cooperation in earwig families provides insights into the early evolution of social life. Am. Nat. 183, 547-557. https://doi.org/10.1086/675364

Fox, J., Weisberg, S., 2019. An $\{R\}$ Companion to Applied Regression., third. ed. Thousand Oaks CA: Sage.

Gingras, J., Tourneur, J.-C., 2001. Timing of adult mortality, oviposition, and hatching during the underground phase of Forficula auricularia (Dermaptera: Forficulidae). Can. Entomol. 133, 269-278.

Grew, R., Ratz, T., Richardson, J., Smiseth, P.T., 2019. Parental care buffers against effects of ambient temperature on offspring performance in an insect. Behav. Ecol. 30, 1443-1450. https://doi.org/10.1093/beheco/arz100

Günther, K., Herter, K., 1974. Dermaptera (Ohrwürmer), in: Helmcke, J.G., Starck, D., Wermuth, H. (Eds.), Handbuch Der Zoologie. Berlin.

He, L., Ou-Yang, Y.Y., Li, N., Chen, Y., Liu, S.Q., Huang, G.H., 2020. Regulation of Chitinase in Spodoptera exigua (Hübner) (Lepidoptera: Noctuidae) During Infection by Heliothis virescens ascovirus 3h (HvAV-3h). Front. Physiol. 11, 1-11. https://doi.org/10.3389/fphys.2020.00166

Huey, R.B., 1976. Temperature, physiology, and the ecology of reptiles. Biol. Reptil. 12, 25-91.

Hutchinson, J.M.C., McNamara, J.M., Houston, A.I., Vollrath, F., 1997. Dyar's rule and the investment principle: Optimal moulting strategies if feeding rate is size-dependent and growth is discontinuous. Philos. Trans. R. Soc. B Biol. Sci. 352, 113-138. https://doi.org/10.1098/rstb.1997.0007

Kearney, M., Shine, R., Porter, W.P., 2009. The potential for behavioral thermoregulation to buffer "cold-blooded" animals against climate warming. Proc. Natl. Acad. Sci. U. S. A. 106, 3835-3840. https://doi.org/10.1073/pnas.0808913106

Kohlmeier, P., Holländer, K., Meunier, J., 2016. Survival after pathogen exposure in group-living insects: don't forget the stress of social isolation! J. Evol. Biol. 29, 1867-1872. 
https://doi.org/10.1111/jeb.12916

Kölliker, M., 2007. Benefits and costs of earwig (Forficula auricularia) family life. Behav. Ecol. Sociobiol. 61, 1489-1497. https://doi.org/10.1007/s00265-007-0381-7

Körner, M., Foitzik, S., Meunier, J., 2018. Extended winters entail long-term costs for insect offspring reared in an overwinter burrow. J. Therm. Biol. 74, 116-122. https://doi.org/10.1016/j.jtherbio.2018.03.021

Körner, M., Vogelweith, F., Libbrecht, R., Foitzik, S., Feldmeyer, B., Meunier, J., 2020. Offspring reverse transcriptome responses to maternal deprivation when reared with pathogens in an insect with facultative family life. Proc. R. Soc. London B Biol. Sci. 287, 20200440. https://doi.org/10.1098/rspb.2020.0440

Kramer, J., Thesing, J., Meunier, J., 2015. Negative association between parental care and sibling cooperation in earwigs: a new perspective on the early evolution of family life? $\mathrm{J}$. Evol. Biol. 28, 1299-1308. https://doi.org/10.1111/jeb.12655

Kryukov, V.Y., Yaroslavtseva, O.N., Whitten, M.M.A., Tyurin, M. V, Ficken, K.J., Greig, C., Melo, N.R., Glupov, V. V, Dubovskiy, I.M., Butt, T.M., 2018. Fungal infection dynamics in response to temperature in the lepidopteran insect Galleria mellonella. Insect Sci. 25, 454466. https://doi.org/10.1111/1744-7917.12426

Lamb, R.J., 1976. Parental behaviour in the Dermaptera with special reference to Forficula auricularia. Can. Entomol. 108, 609-619.

Lehtovaara, V.J., Roininen, H., Valtonen, A., 2018. Optimal temperature for rearing the edible Ruspolia differens (Orthoptera: Tettigoniidae). J. Econ. Entomol. 111, 2652-2659. https://doi.org/10.1093/jee/toy234

Lenth, R. V, 2021. emmeans: Estimated Marginal Means, aka Least-Squares Means. R package version 1.5.5-1.

Li, D., Jackson, R.R., 1996. How temperature affects development and reproduction in spiders: A review. J. Therm. Biol. 21, 245-274. https://doi.org/10.1016/0306-4565(96)00009-5

Li, S.Y., Fitzpatrick, S.M., Isman, M.B., 1995. Effect of temperature on toxicity of Bacillus thurinhiensis to the obliquebanded leafroller (Lepidoptera: Tortrididae). Can. Entomol. 127, 271-273. https://doi.org/10.4039/Ent127271-2

Linder, J.E., Owers, K.A., Promislow, D.E.L., 2008. The effects of temperature on host-pathogen interactions in D. melanogaster: Who benefits? J. Insect Physiol. 54, 297-308. https://doi.org/10.1016/j.jinsphys.2007.10.001

Lucas, É., Coderre, D., Brodeur, J., 2000. Selection of molting and pupation sites by Coleomegilla maculata (Coleoptera: Coccinellidae): Avoidance of intraguild predation. Environ. Entomol. 29, 454-459. https://doi.org/10.1603/0046-225X-29.3.454

Lysyk, T.J., Selinger, L.B., 2012. Effects of temperature on mortality of larval stable fly (Diptera: Muscidae) caused by five isolates of bacillus thuringiensis. J. Econ. Entomol. 105, 732737. https://doi.org/10.1603/EC11359

Ment, D., Iraki, N., Gindin, G., Rot, A., Glazer, I., Abu-Jreis, R., Samish, M., 2011. Thermal limitations of Metarhizium anisopliae efficacy: Selection for application on warm-blooded vertebrates. BioControl 56, 81-89. https://doi.org/10.1007/s10526-010-9329-3

Meunier, J., 2015. Social immunity and the evolution of group-living in insects. Philos. Trans. R. Soc. London B Biol. Sci. 
Meunier, J., Wong, J.W.Y., Gómez, Y., Kuttler, S., Röllin, L., Stucki, D., Kölliker, M., 2012. One clutch or two clutches? Fitness correlates of coexisting alternative female life-histories in the European earwig. Evol. Ecol. 26, 669-682. https://doi.org/10.1007/s10682-011-9510-x

Moret, Y., Rigaud, T., Motreui, S., Troussard, J.P., Moreau, J., 2010. Condition-dependent ecdysis and immunocompetence in the amphipod crustacean Gammarus pulex. Biol. Lett. 6, 788-791. https://doi.org/10.1098/rsbl.2010.0234

Murdock, C.C., Paaijmans, K.P., Cox-Foster, D., Read, A.F., Thomas, M.B., 2012. Rethinking vector immunology: The role of environmental temperature in shaping resistance. Nat. Rev. Microbiol. 10, 869-876. https://doi.org/10.1038/nrmicro2900

Nijhout, H.F., 1981. Physiological control of molting in insects. Integr. Comp. Biol. 21, 631-640. https://doi.org/10.1093/icb/21.3.631

Nijhout, H.F., Williams, C.M., 1974. Control of moulting and metamorphosis in the tobacco hornworm, Manduca sexta (L.): growth of the last instar larva and the decision to pupate. J. Exp. Biol. 61, 481-491.

Pamminger, T., Steier, T., Tragust, S., 2016. High temperature and temperature variation undermine future disease susceptibility in a population of the invasive garden ant Lasius neglectus. Sci. Nat. 103, 46. https://doi.org/10.1007/s00114-016-1373-0

Ratz, T., Kramer, J., Veuille, M., Meunier, J., 2016. The population determines whether and how life-history traits vary between reproductive events in an insect with maternal care. Oecologia 182, 443-452. https://doi.org/10.1007/s00442-016-3685-3

Régnière, J., Powell, J., Bentz, B., Nealis, V., 2012. Effects of temperature on development, survival and reproduction of insects: Experimental design, data analysis and modeling. J. Insect Physiol. 58, 634-647. https://doi.org/10.1016/j.jinsphys.2012.01.010

Rozen, D.E., Engelmoer, D.J.P., Smiseth, P.T., 2008. Antimicrobial strategies in burying beetles breeding on carrion. Proc. Natl. Acad. Sci. U. S. A. 105, 17890-5. https://doi.org/10.1073/pnas.0805403105

Sandrin, L., Meunier, J., Raveh, S., Walser, J.-C., Kölliker, M., 2015. Multiple paternity and mating group size in the European earwig, Forficula auricularia. Ecol. Entomol. 40, 159166. https://doi.org/10.1111/een.12171

Stamp, N.E., 1990. Growth versus molting time of caterpillars as a function of temperature, nutrient concentration and the phenolic rutin. Oecologia 82, 107-113.

Stamp, N.E., Osier, T.L., 1998. Response of five insect herbivores to multiple allelochemicals under fluctuating temperatures. Entomol. Exp. Appl. 88, 81-96. https://doi.org/10.1046/j.1570-7458.1998.00349.x

Therneau, T.M., 2020. coxme: Mixed Effects Cox Models. R package version 2.2-16.

Thesing, J., Kramer, J., Koch, L.K., Meunier, J., 2015. Short-term benefits, but transgenerational costs of maternal loss in an insect with facultative maternal care. Proc. R. Soc. London B Biol. Sci. 282, 20151617. https://doi.org/10.1098/rspb.2015.1617

Thomas, M.B., Blanford, S., 2003. Thermal biology in insect-parasite interactions. Trends Ecol. Evol. 18, 344-350. https://doi.org/10.1016/S0169-5347(03)00069-7

Tourneur, J.-C., Meunier, J., 2020. Variations in seasonal (not mean) temperatures drive rapid adaptations to novel environments at a continent scale. Ecology 101, e02973. https://doi.org/10.1002/ecy.2973 
Tourneur, J., Cole, C., Meunier, J., 2020. The first of five moults of Forficula auricularia L. (Dermaptera: Forficulidae). Can. Entomol. 152, 783-789. https://doi.org/10.4039/tce.2020.57

Vogelweith, F., Körner, M., Foitzik, S., Meunier, J., 2017. Age, pathogen exposure, but not maternal care shape offspring immunity in an insect with facultative family life. BMC Evol. Biol. 17, 69. https://doi.org/10.1186/s12862-017-0926-y

White, T., 1978. The importance of a relative shortage of food in animal ecology. Oecologia 86, $71-86$.

Wojda, I., 2017. Temperature stress and insect immunity. J. Therm. Biol. 68, 96-103. https://doi.org/10.1016/j.jtherbio.2016.12.002

Wojda, I., Jakubowicz, T., 2007. Humoral immune response upon mild heat-shock conditions in Galleria mellonella larvae. J. Insect Physiol. 53, 1134-1144. https://doi.org/10.1016/j.jinsphys.2007.06.003

Yilmaz, S., Karabörklü, S., Azizoğlu, U., Ayvaz, A., Akbulut, M., Yildiz, M., 2013. Toxicity of native Bacillus thuringiensis isolates on the larval stages of pine processionary moth Thaumetopoea wilkinsoni at different temperatures. Turkish J. Agric. For. 37, 163-172. https://doi.org/10.3906/tar-1201-21 